\title{
Quadras populares e adjacências
}

\author{
OSWALDO ELIAS XIDIEH
}

\begin{abstract}
Aos amigos:
Yoshiko Tanabe Mott, Zenir Campos Reis, Marineis Novais Ayala, José Antônio Pasta Júnior Eloisa Faria Scarabotolo, Paulo de Salles Oliveira Ataliba Monteiro de Moraes, Mena Pinheiro, José Carlos Borin, Edmur Fidêncio de Gody, Francisco Assis de Souza Lima com muito afeto.

E a Elpídio Miranda, repentista e cantador, minha eterna gratidão pelas quadras sujas, que marcam um instante de profunda mudança do e no Brasil!

Elpídio Miranda regressou à Bahia em de fevereiro de 1991. Trabalhava como guarda em Marília.
\end{abstract}

A S QUADRINHAS, as quadras, além da cantoria de pretos, da Louvação a São Benedito e da ronda infantil foram acumuladas, quase todas, nestes últimos 50, ou mais, anos. A mor parte delas eu as ouvi desde minha infância e, mais tarde, em diversos lugares do Estado de São Paulo, da Bahia, do Ceará e da Paraíba. Nunca foram objeto de pesquisa sistemática. Aconteceram, apenas. Por isso não posso negar a contribuição que me foi dada por alunos secundaristas de Jacareí, Jaboticabal e por amigos de Mogi das Cruzes, Suzano e Poá. Ademais, ainda hoje, aqui em São Paulo há sempre um amigo a confiar-me o que o povo pensa e diz de certas ... coisas e pessoas, assim como zomba e ri de sua importância - que o povo chama de "panca"!

Farei referência àlgumas delas - às "safadas" e às muito "sujas", talvez.

Esse material, na sua maior parte, ficou, como simples recordação, no fundo da gaveta. Hoje, sinto não estar em condições de tratá-lo condignamente. No entanto, revendo-o com muito cuidado, não procurando saber ser perfeito ou não sob o ponto de vista gramatical, estético e poético, verifica-se que consoante em outras formas e gênero de literatura popular oral ou escrita, por ele transitam valores e julgamentos consagrados pela experiência popular, posições e códigos 
quanto à justiça, à moral, à política; princípios e crenças religiosos, índices da sabedoria do povo que também são não apenas do "popular". Coisas que duram, enquanto subsiste uma estrutura social com possibilidades de permanência? Que sim, dizem! Mas será que é exatamente isso?

Contudo, basta atentar, algumas quadras - principalmente na ronda infantil refletem a "erosão" que a dinâmica social provoca nos padrões morais, transformando-os, inexoravelmente, ao impacto de tudo quanto há de novo a emergir da mudança social.

Os informantes - dentre os que não esqueci - foram, em Pilar, Francisco Bonilha de Godoy, o Chico Laranjal; em Taquaritinga, "Seo" Galvão e Celino Pimentel; em Mogi das Cruzes, Iracema Nunes da Siqueira; em Jacareí, Mena Pinheiro; em Ururaí, Pedro Jalageas e Antônio Fernades; em Poá, "Seo" Selma; em Suzano, Daniel Grijo. Na Paraíba, Tita, motorista da Faculdade de Filosofia. Na Bahia, um bêbado. No Ceará, Crato, "Seo" Pedro, guarda ou servente da Faculdade de Filosofia, em 1969, graças à bolsa que me foi concedida pela Ford Foundation, projeto Literatura de Cordel. E o resto? Só Deus sabe em quantos velórios e festinhas de aniversário, bate-papos de botequim, em conversas apanhadas de outiva.

Como classifiquei esse material? Em quadras "santinhas", "singelas", "sabidas", "safadas" e "sujas". Além das quadras, junto uma cantiga de pretos, uma Louvação a São Benedito e uma ronda infantil. Devo-as, respectivamente, à mãe Domingas, a João da Cruz e Iracema Nunes, às crianças de Poá.

Cantiga, Louvação e ronda, serão tratadas à parte. Quanto ao conjunto aqui registrado, será que devo evocar o ideário popular que o rege, consubstancia e caracteriza?

Parece-me óbvio frisar a delicadeza, a simplicidade das "santinhas" e das "singelas", assim como o rigor das "sabidas", ou a malícia das"safadas". Na verdade, o interesse de quem escreve estas breves linhas é não permitir que essas contribuições populares - nem todas me parecem ser - se percam para sempre numa gaveta. Alguém - confio na gente que vem vindo por aí - lhes dará tratamento mais satisfatório.

A cantiga dos pretos, conservada por mãe Domingas, eu a ouvi em 1922 na minha infância. Mais tarde, em 1934, ela m'a confirmou. Pareceu-me, então, apenas um fragmento da cantoria. Apesar disso, eu a registrei.

Já a Louvação a São Benedito, ouvida em duas ocasiões, a primeira em São João de Caputera, Mogi das Cruzes, 1939 e, a segunda, na Ilha dos Búzios em 1952, sempre me pareceu instigante exatamente por parecer reverenciar uma entidade religiosa compósita. Sempre evito que a imaginação me atropele, mas, neste caso, é preciso dar-lhe alguma vazão.

Então, o que fazer com um santo que rege aberturas, abre caminhos, detesta trapaça e, para arrematar, bebe cachaça ? 
Gente da minha geração deve lembrar-se das antigas procissões, pois não era a irmandade de São Benedito, com opas pretas, tocheiros, estandarte e andor do Santo que encabeçava o préstito? Pois não se dizia que se esse santo não estivesse na frente, aconteceria qualquer problema e a procissão seria um fracasso?

Cá entre nós alguém precisa verificar se foi o preto que promoveu mais essa "andança" de Elegbara, Elegba ou Exu - como queiram - a Santo, ou, então, que instituição religiosa, deliberadamente, permitiu, para fins de pacificação ou acomodação de crenças, que tais entidades africanas assumissem um papel mais "decente", revestindo-as de burel, calçando-lhes sandálias, atando-lhes um rosário à cintura.

Além disso, para garantir a domesticação, um menino Jesus foi-lhes implantado aos braços. Tudo para tornar-lhes impossíveis os arroubos por demais dionisíacos e ambíguos? E olhem, isso já vem de Portugal, acho eu!

Marafa no Santo, minha gente! Será que convém um pouco de fundanga?!

A ronda infantil registrada em Poá em 1942 prendeu-me a atenção por dois motivos, principalmente, entre outros.

Em primeiro lugar, a cantiga "chave", por assim dizer e para evitar palavrório estrangeiro, não evocava nenhum tema tradicional, como, por exemplo, o "Senhora Dona Sancha", "Senhora bela condessa", o "Capelinha de Melão", o "Caso do Antoninho" e isso para não falar de cantos mais antigos como "Surupango da Vingança" ou "Morte de Juliana".

O que ouvi foi um espanto: - "Menina da perna torta - Da saia espandongada - Boca de Jacaré, etc, uma espécie de arremedo das velhas canções.

Em seguida as quadrinhas recitadas - algumas estranhamente seculares atirei um cravo n'água - outros parecendo variáveis ou fragmentos de "se esta rua fosse minha..., e outras muito comuns. E havia aquela que ditava às crianças a moral da época - "Sou menininha da perna grossa - vestido curto mamãe não gosta!" Pobre mãe da época de quarenta! Se ela suspeitasse das coisas que dali a pouco viriam por aí!

Se ela visse a tevê, que entrega a domicílio todas as coisas "explícitas"!Se ela assistisse à eclosão da mini-saia, do top-less, do fio dental e doutras demonstrações que fazem a crista da moda! Deixa prá lá! Deixemos a natureza, isto é, a sociedade seguir seu rumo!

Muitas vezes me perguntei que fim tiveram as velhas canções. Aos poucos me informaram que nalgum tempo foram cantadas em orfeãos de escolas secundárias, inclusive em Marília nos anos 50. Eloísa Faria Scarabotolo e Yoshiko Tanabe Mott lembram-se desse tempo.

Mas, agora? Só me resta louvar-me em Carlos Drummond de Andrade (1), testemunha fiel do abrigo que Villa-Lobos, amorosamente, deu a essa cantoria antiga, quase esvanescente. 
Um pouco acima deixei transparecer minha desconfiança quanto ao "popular" dalgumas quadras registradas. Desconfiança idêntica à que eu sinto pelas músicas "populares" hoje na crista da moda e que se intitulam "sertanejas" quando na verdade, são apenas "urbanejas": pastiche de tango argentino, rumba, bolero, coisas do caribe. E a letra? Gemidos de bichos no cio, popularesca à perfeição, "urbaneja" e mesmo "suburbaneja".

Contudo, com relação à música, à letra que ela veicula e à dança que ambas podem inspirar, e que se colocam como populares, é preciso paciência, muita indugência, tendo-se em mente como se desgastaram pela caducidade os costumes, tradições, religiões, preceitos - que sei eu - e, não raro, sob a férula da propaganda comercial e dos grupos econômicos. Lembram-se do caso Benetton? Foi um tapa na cara! Mas, para impor o uso de nova mortadela tenham a certeza, faríamos qualquer trapaça com a memória de heróis ou a virtude de um santo, desde que rendesse alguns miúdos!

Desse mundo em mudança e decomposição está saindo uma espécie de neopopular. Carente de regulamentação? Pois que venha com todas as virtudes ao contrário, ou nem ouse aparecer!

Dizem que o diabo tanto enfeitou o filho que acabou furando-lhe os olhos. É que quase saí do meu rumo, quando o meu desígnio era tentar propor a que fontes a poesia popular recorre ou em que ela se dessedenta.

Creio firmemente, de pés juntos, que é o mundo, a natureza, a vida, as mil e umas coisas implicando a vivência de e com todos os seres, construindo simultaneamente as fontes de quaisquer poesias - de um lado o universo concebido com uma gramática normativa para os grupos que se elitizam e de outro o mundo vivido e assumido, aprendido e sabido, não pela gramática, sofrido e incorporado, a pulso pela experiência do homem comum, sem nome, sem escola, sem mestre a não ser a vida! A vida que o incorpora? Diferente? Sim, dos que fazem o universo à sua imagem e semelhança.

Menino em Taquaritinga, lá por 1927 ainda no grupo escolar, perdi um colega e meu pai me fez ler no jornalzinho local algo que me assombrou durante muito tempo: "Zizinho, nem entrado na feliz adolescência, faleceu vítima de estúpido acidente na manhã de ontem; era um triste domingo! À tardezinha, ontem mesmo, ele voltou à companhia de sua saudosa mãe e melancólica chuva fina e fria foi sua deradeira companheira, desfeita em lágrimas sobre sua campa. Nossos pếsames ao digno progenitor".

Moleque, eu conhecia a chuva criadeira, a chuva de manga, a chuva intrometida do veranico e as chuvas bravas; do vento da Bocaina, nem falar! Mas, foi só no ginásio que vim a saber que há correntes literárias, as românticas, que comprometem, para seu uso e abuso, seu feitio e balda, Deus e todo mundo! Aí está uma das fontes! Mas como, se a minha antiga gente não lê, e se lê é algo já mastigado e digerido?

Se não lê, escuta! Vai! 
Do monumental corpus do romantismo - isto é, daquilo que foi considerado um dia o popular segundo a ótica da elite literária atuante - ao povo comum coube como herança os seus detritos: sugestões, imagens, volteios de linguagem, medalhões repetidos, vulgarizados por fontes secundárias de comunicação, como o circo, os jornais interioranos dominicais, folhetos de propaganda de macumbeiras e adivinhas, os grupos amadores teatrais de província, e que se perpetuam através do tempo nas camadas medianas e básicas da sociedade. Os temas fascinantes do romantismo: morte, doença, brevidade da vida, melancolia, resignação, amor infeliz, angústia, cemitério, ruínas e um punhado de outros mais, terminam por formar uma crosta na sensibilidade da gente e no seu entendimento.

Isso tudo pode ser registrado pelo convívio e, também, pela leitura.Um tipo de publicação que circulou ou circula ainda entre as camadas básicas: Elvira a morta virgem, Tristezas à beira-mar ao lado dalguma "erudita" como a Escrava Isaura e algum romance como a Sepultura de ferro, do qual só conheci um fragmento, sem data ou outras indicações. E no teatro popular, coisas como os Três sargentos e Paixão e morte de Jesus Cristo. Ainda como contrapeso os sonetos dominicais dedicados às mães, aos novos defuntos, aos que estão nascendo. Ademais, como variantes obrigatórias, as embrulhadeiras de balas e as catadeiras de café cantavam o "Perdão Emília", se roubei seus beijos - "Perdão Emília que eu sou um desgraçado" ou o "Ó Geny, meu sincero amor" até a boca da noite ou, mais ainda, se havia hora extra!

Corria entre as domésticas e costureiras uma espécie de romanceiro, coletânea de versos para serem cantados com a música do "Perdão Emília".

Mas, doutro lado temos alguns poetas identificáveis, não como difundidores e sim como escritores mesmo. No rol das presentes composições, temos as de três deles: Rafael Lofrano, Reynaldo Pinceta de Taquaritinga e Zizica Nunes de Mogi das Cruzes. Com os dois primeiros encontrei, há tempos atrás, o livrinho de Alfred de Musset, Confessions d'un Enfant du Siècle. Em posse de Zizica, um livro psicografado, atribuído a Victor Hugo, se não me falha a memória, intitulado $\mathrm{Na}$ sombra e na luz. Além disso, Zizica mantinha na estante a obra completa de Mme Delly.

O que acho dessas andanças? Nenhum desdouro para ninguém. Enfim, todos ajudam a fazer a história disto ou daquilo. E isso é ou não mudança, movimento, criação, vida, beleza e alegria? A propósito dessa presença literária erudita nas referidas quadras, espero que cada um faça, a seu gosto, a exumação dos seus fósseis! Mas com relação ao realmente popular - tradicional e folclórico - tenham delicadeza e tato para destacar os germens - coisa viva - que nele estão implícitos!

Já é tempo de tratarmos daquilo que é a fonte da poesia popular - mas esse conceito popular nós percebemos e sentimos o quanto ele tem de complacente, sediço, confuso e impróprio a designar, incluir a grosso modo toda e qualquer manifestação dita cultural à margem do mundo erudito, acadêmico, das classes ditas superiores ou dos que estão a serviço dessas injunções. Desígnios geralmente mascarados dos grupos de dominação e discriminação sociais. 
Nesse conceito tão liberalmente arrumado agrupam-se como corós de goiaba podre todos os popularescos imagináveis e concebíveis! V.g.a dança lambada, descendente do fuso, por sua vez filho do parafuso e agora dançado em grupo suruba, comuns nos antigos bordéis e que hoje, na falta deles, passam às rondas infantis!

Agora, vamos devagar com o andor que o santo é de barro!

Então deixando os terrenos movediços e as áreas insalubres da cultura instituída, fixemos nossa atenção no tradicional e folclórico sem lidar com conceitos, observando e considerando o conteúdo dessas quadras, as coisas nelas implícitas, catalogadas pela experiência anônima e milenar. Coisas que desvendam o universo dos seres: plantas, animais, homens, espíritos e deuses!

E onde estão essas coisas? $\mathrm{Na}$ pele nossa, em nossos olhos que miram mais além, na certeza de que tenho a cada amanhecer que retomo meu lugar nessa experiência com todos os seres de agora e de sempre, no eterno presente dos contos, das lendas, das fábulas, dos mitos; dos ditados, das simpatias, das rezas, dos cantos, dos anexins, das adivinhas, do trava-linguas... Aí está a fonte da poesia popular deveras.

É confusão minha, uma espécie de antologia desbragada? É . Então tratem de conseguir coisa melhor. Não vou dizer que dou uma banana pro povo, nem estou aí !

Mas, vamos agora ao que pode nos interessar: de que maneira lidar com essa poesia e entendê-la, sem, no enteanto pretender ensinar como ou dizer como, porém ir fazendo, fazendo até onde possível, tomando para exercício três ou quatro das quadras aqui registradas e considerando, quando possível, os dados da História como fontes secundárias eruditas dos relatos populares.

Quatro quadras em exame

28 Se não chove até São José, arrume a trouxa e sua famiage. Pegue logo a estrada, dê no pé, pra se livrar da triste estiage!

Seo Pedro, Crato, 1969

Lembra-se ainda do nosso encontro lá no Crato, em 1969, mês de julho? Lembra-se, Pedro? Tempo ameno, o Cariry reverberava, o fantasma da seca estava alongado por outras bandas, realizara-se a promessa de São José:

São José cuida do milho,

Com amor e devoção,

Pra ornar com muito brilho,

A bandeira de São João!

É, naquele junho houve fartura, era em 1969. Mas você continuou e disse: como choveu até o dia de São João, não houve carestia e ninguém careceu andar por tristes anduras de miséria, fome e morte! Em boa parte do Ceará. 
Você me falou, falou e disse, e essa fala antiga ficou-me gravada com ferro em brasa no coração, como muitas outras de outros lugares, de outras gentes como você - as minhas gentes - que só tem como amparo e valia o Deus nosso e seus Santos que há quinhentos anos lutam para nos acudir do descaso dos que ainda não descobriram que somos um povo só, uma nação, bastante por si mesmos, mas precisados de reconhecimento e vez.

Você hoje deve ser também um encantado. Sendo assim, faça das suas, por experiência, por aí mesmo no Ceará, faça estágios mais demorados na Assembléia, em Fortaleza. E esperemos. Muita coisa boa e pioneira já aconteceu nessa região de luz: abolicionismo - lembra-se? Agora, libertem o seu próprio povo do abandono; ou o povo do Ceará não pertence ao grupo que o governa? Branquetudes remanescentes? Isso passa!

Pedro, não houve outro jeito de lidar com material folclórico a sua quadra. Faltava-lhe a história que lhe foi recusada por seus donos de sempre. E, sem a História, o Folclore despenca nas névoas do puro imaginário! Porém, há um recurso: Estória! Referente à experiência do Ceará. Estória é o relato minucioso dos ciclos de miséria, fome, êxodo, desepero de um povo que só conta com São José.

A quadra 77 é suja e eu não queria, a rigor, lidar com ela. É grosseira e brutal e, no entanto, de um significado que ultrapassa, de longe, os termos da nossa moral comum. Vem de um tempo arcaico em que o mundo era apenas a moldura de eterna fecundação!

Pouco importa se hoje Padre Inácio e Sigismundo ocupem, no processo, cargos tão importantes. Padre Inácio já se consagrou tradicionalmente nos contos e nos cantos escatológicos há séculos. Quanto a Sigismundo, que deve ter penetrado o folcore nosso mediante grupos étnicos europeus - ou não? -, enfrentamos alguma dificuldade: é que Sigismundo quando não arrasta seus atributos como o Padre Inácio, surge, vez ou outra, como pustulento, símbolo da sujeira e da vermina.

Perguntam-me dos senhores ancestrais de tão jactanciosa dupla? Posso oferecer opções. Temos, de um lado, o rubro Jurupari e, do outro, o clássico, gregoromano, brônzeo Príapo?

Estes versos (quadra 10): "Padim Ciço é um encantado, andeja fazendo o bem..." desvelam um mundo em que a tradição e a fantasia alimentadas no sagrado rompem as barreiras da realidade construída pelos sentidos e discursos. Assim é que a vida liberada de espaço e tempo, nascimento e morte, estua numa outra região que vai da absoluta claridade e por graduação vai penetrando no sonoite, no Pui-djarê-djapú, faixa em sombras e clarões cambiantes, que embaralham, perturbam, enganam e permanentemente envolvem a terra. 
Essa faixa que vai da luz do crepúsculo, do céu até o seio da terra, perdendo-se nas trevas no momento em que nela penetra, essa faixa é o caminho por onde transitam espíritos de luz, os santos, os beatos, isto é, todos os benditos, que morreram e no entanto vivem para o bem dos homens e glória do Senhor!

Mas, cuidado, à sua cabeceira estão os que foram arrebatados em vida; Elias, aos pés de Deus, que empunha a espada flamejante para o dia do Juízo.

E há os penitentes, com contas a pagar, de trânsito limitado, até o dia em que os anjos da balança os considerem redimidos.

Vamos devagar que há os danados, besteando, sem rumo, crucificando-se na sua desesperação! Todos os malditos, todos os judas, todos os capitães do mato, todos os senhores de escravos e de engenhos que mutilaram de corpo e de alma as criaturas perfeitas segundo a vontade do Pai. Ali estão como feras se dilacerando os que adulteraram as gentes desvalidas de qualquer tempo, de qualquer lugar: ali ficarão até o último trago ou, finalmente, quando Deus sentir-se curado de todas as dores que lhe foram causadas por eles e sentir-se servido. As entidades, os espíritos, os poras - da crença tupi-guarani - os andaços da doença, as almas ou espíritos da terra - da água, do fogo, do ar e da terra mesmo - esses elementos são livres e não caminham por essa faixa porque eles não são bons nem maus, não têm pecados a pagar e só têm como ponto de referência um Deus eterno e as coisas são praticadas de acordo com a vontade Dele.

Meu amigo e companheiro, minha toada continua, basta querer ouvir. Outros beatos, outros encantados já estão à vista! Se você não entende, não faz mal: o povo, que milagrosamente desponta aqui e ali, sabe! o povo conhece os sinais do Mito que precedem, auguram e revestem os santos, os heróis, os beatos: vida longa, doença, sofrimento; vítima de perseguição e calúnia; afã de socorrer e ajudar; resistência milagrosa às desgraças; a palavra boa até ao morrer!

Olhem, frei Damião já rompe o casulo! Nalgum dia, alguém ouvirá vozes anônimas, sussurrando:

Frei Damião é um encantado, que anda por aí só fazendo o bem, não tem encontro marcado, ninguém sabe quando vem. Pode estar muito afastado, mas a seu lado também, de beato disfarçado!

Amen!

Ítalo Calvino (2), citando a introdução das Metamorfoses de Ovídio, transcreve: "Existe no alto do céu uma via que se vê quando faz bom tempo. Láctea se chama e brilha justamente por sua brancura. Por ali passam os deuses, dirigindose à moradia do Senhor Supremo dos Trovões, no palácio. À direita e à esquerda, com as portas abertas, acham-se os átrios dos deuses nobres, sempre cheios de 
gente. A plebe mora dispersa noutros lugares. Os deuses mais poderosos e ilustres estabeleceram aqui seu domicílio em frente [...a fronte potentes/caelicolae clerique suos possuere penates].

Colocava-se pois a Via Láctea como domicílio opcional, ponto de passagem, dos deuses, para o desempenho de suas funções entre Júpiter tonante e os mortais.

Ovídio faleceu em 17 d.C. Vivesse nos tempos de Constantino a Teodósio (3), teria assistido a profundas e extensas metamorfoses; à liquidação do seu mundo e ao despejo dos seus deuses das mansões celestiais.

Foi assim que a Via Láctea desocupada passou à assistência dos santos. De São Roque, dizem alguns, com seu cachorro e sua ferida. Quando cansou da andação pelas estradas, foi substiuído por São Tiago que até hoje está lá. Sacrifício? Por piedade, é o new look para que a terra não caia no abismo se o colar de estrelas for rompido, conforme se aprende na quadra 15.

E, enfim, o que fazer com as demais quadras? Nenhum árduo esforço para se constatar que algumas delas se aglutinaram em razão da experiência de vida do dia-a-dia a arcaicos anexins, benzimentos e rituais mágicos de afastamentos, creio eu. Verifiquem-se as quadras 59 - ritual e prática para capar macumbeiros; 39, 43 e 45 - quadras à base de anexins; 14 - simpatia medieval para curar impingem.

Isso não é tudo. Muitas coisas podem ainda ser constatadas, porém, desta vez em dois momentos da história política brasileira contemporânea.

Antes, contudo, quero lembrar-me do que me dizia há muitos anos padrinho Bino, caboclão lá de Pilar do Sul, de origem francesa. Pois que era o Filisbino Murat de um grupo de imigrantes depois da queda de Napoleão I. Esse é uma achego folclórico, ao que logo mais comentaremos. Quer dizer: recorremos a conceitos não-científicos para abordar a história, conceitos que integrariam, possivelmente, ou fontes secundárias da história segundo os eruditos que estabelecem, conforme suas experiências restritas às ideologias, filosofias e preferências próprias de cada época, o que são tais fontes primárias.

Pois bem, o Bino dizia: “- Conheci o II Império Brasileiro, vi nascer a República que de República tinha apenas o nome. Era uma República de monarquistas, fazendeiros e conselheiros imperiais. Vi as Revoluções de 1924 e 1930. A partir de 30 e até o que se chama de "Estado Novo", o Brasil coloca-se na posição de Republiqueta Americana com o seu respectivo ditador. Enfim, tomou corpo e cresceu tudo aquilo que o Imperador evitara".

Então não custa nada entender o que o Euzebinho de Morais - lembra-se, tinha aquele armazém ao lado da matriz - me disse um dia: 
"O Brasil é uma lua. Lua que tem só duas fases: a nova, de sete dias, e a mingunate, de vinte e um. Na nova, ele cresce e parece renovar-se; na minguante, tudo vai água abaixo".

Lá em Pilar do Sul, muitos velhos recordam-se ainda de Bino e do "Seo" Euzebinho, que morreram antes dos minguantes de 1964 e de 1989-1992...

No entanto, evoco também, para tranqülizar os senhores universitários, o testemunho de Walter Benjamin (4), expresso na tese 3 sobre filosofia da história: "O cronista que se põe a contar os acontecimentos sem distinguir pequenos e grandes presta tributo à verdade de que nada do que alguma vez tenha acontecido pode ser considerado perdido para a história. Certamente só uma humanidade redimida há de assumir todo o seu passado. Isso quer dizer: tão-somente à humanidade redimida o passado se torna citável em cada um de seus momentos. Cada um dos seus instantes vividos se torna uma citation à l'ordre du jour - dia esse que é exatamente o último".

Não quero dizer que isso vale para os testemunhos secundários dos acontecimentos históricos, denominados folclóricos ou populares: penetras sob o pano do circo da História erudita. Mas essa História erudita que se modela e se constrói - após o fato - pelos grupos de dominação em quaisquer sociedades humanas não é apenas a história dos interesses desses grupos? Que valor, portanto, dar à contribuição do outro que assiste, julga e elabora outra história? Qual será a citation à l'ordre du jour? Esse último dia de uma humanidade redimida? Perguntem, cavalheiros, a um homem comum o que ele acha dos políticos como filhos da democracia e ele lhes dirá, de cara aberta e boca cheia, que eles são é mesmo filhos doutra coisa...

Não acreditam? Pois então vejamos o que ocorreu em Jaboticabal quando, após a Segunda Guerra, tivemos uma lua nova com o fim do Estado Novo e a reabertura dos partidos políticos. Esse é um dos momentos que mais acima enunciei e em que o folclore complementa a história ou lhe desmascara a efígie cunhada de acordo com estranhas circunstâncias e interesses de algum grupo de dominação, daquém ou de além mar.

Mas, reportemo-nos àquele dias de abertura em que a palavra democracia era apenas um conceito viciado ou esvaziado por falta de uso e, sem uso, não tinha mais lugar nem na imaginação. E aconteceu que pela porteira arrombada purgou uma geração inteira de políticos de outiva e no nível da patuléia e do faz de conta assomaram aqueles que ora eram tidos como legais e, na mor parte das vezes, por minguantes inteiros, como subversivos.

Aos primeiros coube a saga do berreiro eleiçoeiro nos palanques e que culminava no festunço desbundado nos bordéis. Mas, essa balda é, afinal de contas, tida como democrática e normal, considerando-se que é isso que revela as fezes suas.

Aos segundos coube, por décadas e décadas, sua semeadura em covas pelo território nacional e cujas ossadas suas famílias hoje reclamam com as correspon- 
dentes indenizações. Desse modo, numa espécie de barganha, a milica justificada e famílias recompensadas abraçam-se e declaram que tudo está bem, que o que passou, passou; deixa pra lá, Bebé!

Mas voltemos a Jaboticabal. Naquele tempo, como professor no colégio estadual, assisti à inquietação de meus alunos, já homens feitos, que vinham me anunciar a vinda daqueles políticos de araque: - "Professor, os artistas estão chegando". Mas, que artistas? "As meninas estão delirando, tem o Auro de Moura Andrade, o Emílio Carlos e o Quemalmazão (?)".

Meus relatores, dentre os que me recordo: João Maricondi, Carlos Pimentel e João Gaglianoni que até a exaustão assistiram à representação teatral desses senhores. Que Deus esteja com meus alunos e que hoje devem ser tão idosos como eu e que deixaram duas quadras, as de número 54 e 55 , que expressam que o povo (essa coisa que não tem peso em nada, né?) pensou, viu e julgou com validade para os dias atuais e como!

E o segundo momento, antes anunciado, teve início com o minguante de 1964 e que durou até 1984, após o que houve uma encenação de vida democrática, com eleições indiretas, mortes misteriosas, povo gritando na rua, caras pintadas em oposição aos caras branquelas das tais eleições. Foi difícil abrir mão da carniça, né Bebé?! Ilusão pura. Em 1990, depois dos dois do centenário da corrupção, houve eleição direta. Espanto nacional: coisa pior aconteceu, que por decência vamos denominar de Era Imexível porque até hoje, se mexida, fede caramba! Ainda vai catingar com alguns mamulengos aqui e outros sacrispantas por todos os lados do pedaço.

Desse período, de 1990 a 1992, uma criatura notável emergiu do povo comum, que a elite chama de filho das ervas ou populacho: Elpídio Miranda, baiano, guarda particular noturno em Marília. Imagine-se a combinação de Gregório de Matos Guerra e a nossa Dercy Gonçalves. Uma glória!

Em 1989 eu já estava paralítico e então meu amigo Elpídio vinha ver-me todos os dias e, ao entardecer de cada dia, cantava para mim suas derradeiras quadras, pois ele é repentista e violeiro.

Não vou relacionar todas essas quadras; destaco somente as menos sujas, colocadas por Elpídio dentre as imexíveis artes daquele um. Aqui vão as quadras: 38 - Sobre a eleição e a poupança; 61 - Não vá sair de baiana na festa do roquinrio; 63 - Cai tanto raio em peroba; 65 - Por que não desencarna; 75 - Que tipo de cabeça tem esse presidente; 76 - Onde deve ser enfiado o saco roxo dele.

Não sei se as coisas hoje estão melhores. Uma lua nova para trabalhadores, sem-terras, desempregados, professores primários e crianças não vai acontecer tão já. Careceria outra Princesa Isabel disposta a sacrificar de novo alguma coisa para libertar esse povo dos íncubos e súcubos, mequetrefes e estafermos que fornicam a nação. 


\section{Quadras populares:}

Santinhas,

Singelas,

Sabidas,

Safadas e

Sujas.

\section{Santinhas}

1 A Virgem vai num barquinho,

Lavrado de paina e seda.

$O$ vento le ajeita o caminho,

um anjo le alumia a vereda.

Um cantador, Igreja de Nossa Senhora das Estrelas,

(Itapetininga, agosto 1936)

2 O amor de Deus está presente,

Em todas as criaturas desta terra,

Porque Deus é pai clemente,

Vai remediando o que o homem erra?

(Pilar, 1937)

3 Eu choro, rogo e peço

Ajuda do Senhor,

Recurso que conheço,

Neste mundo de dor.

Num velório (Poá, 1939)

4 Deus é dono do tempo,

Mas cada dia que passa

Tem seu Santo protetor:

Segunda é de São Benedito e das almas,

A terça, de Santo Antônio.

Na quarta São João Batista,

A quinta-feira é de São Pedro,

Sexta-feira, das almas que sofrem,

Nas sombras do purgatório.

Todos os Santos no sábado.

No domingo Nosso Senhor.

(Jacareí, 1949) 
5 Rosa Imaculada,

Ramo de jasmim,

Oh! Virgem Imaculada,

Amparo para mim.

Mena Pinheiro (Jacareí, 1964)

6 A Virgem Maria menina,

Brincava fazendo flores,

Vinham os perfumes da campina

E do arco iris as cores!

Mena Pinheiro (Jacareí, 1964)

7 Meu Jesus pequenininho,

Cê não cabe em minhas mãos.

Mas se ajeita direitinho

Dentro do meu coração.

Daniel Grijo (Suzano, 1968)

8 Você refuga o Santo?

Deixa o Santo de lado:

Ele continua santo

E você, um desgraçado!

Um repentista (Crato, Ceará, junho 1969)

9 São José prepara o milho, com amor e devoção, pra ornar com muito brilho a bandeira de São João!

Seo Pedro (Crato, junho 1969)

10 Padre Ciço é um encantado, Andeja fazendo o bem.

Não tem encontro marcado, Ninguém sabe quando vem.

Pode estar muito afastado

E junto a você, também

De beato disfarçado!

Seo Pedro (Crato, junho, 1969)

11 Padim Ciço morreu?

Deus nos livre desse engano!

Ele mesmo se escondeu

$\mathrm{Na}$ igreja do Vaticano!

Seo Pedro (Crato, junho, 1969) 
12 Ah! Virgem poderosa,

Flor de manacá,

Na vida e na morte,

Sempre me valerá.

Seo Daniel Grijo (Suzano, 1970)

13 Meu amparo é Jesus Cristo,

Fortaleza e esperança,

Por seu amor eu existo,

Derradeira segurança.

Seo Daniel Grijo (Suzano, 1970)

14 Empigem rabiche,

Que coça e pinica,

A Senhora Santana,

Mandou te secar,

Com cuspe da boca,

E cinza do lar.

(Mogi das Cruzes, 1970)

15 São Tiago anda pelas estrelas

Que rodeiam tudo vê um colar

Sem descanso, noite e dia pra vigia-las

E impedir a Terra de no abismo tombar.

(Mogi das Cruzes)

\section{Singelas}

16 Capelinha de melão

É de São João.

É de cravo é de rosa

É de manjericão.

Lembranças de Pilar

17 Um botão de rosa,

Veio do Buri,

Cheira tão gostoso, morena,

Cheira abacaxi.

Fandango (Pilar, 1922)

18 Um cutielo verde me falou

Pra não me desesperar

A mulher que a gente amou 
Logo, logo vai voltar.

(Mogi, 1938)

19 A lua é minha amiga,

O sol o meu protetor,

A Estrela Guia me guia

Aos braços do meu amor.

(Poá, 1945)

20 Longe dos olhos longe do coração,

Dizem os que não têm sentimento.

No fundo do meu peito com emoção

Guardo seu amor, sua voz, cada momento!

Alguém cantando (Mogi das Cruzes, 1952)

21 Se alguém já lhe fez um grande bem, Isso é dívida que nunca mais acaba!

O coração vai lhe ensinar, porém,

Que o amor só com o amor se paga.

Emília Jorge (Taquaritinga, 1953)

22 Meu amor não tenhas medo,

Por eu estar longe de ti,

Sou teu eterno namorado,

Desde o dia em que te vi !

(Mogi das Cruzes, 1953)

23 As cores que temos no mundo

São de muita instrução:

Amarelo é desespero,

$\mathrm{O}$ verde é esperança,

E o roxo, solidão.

Azul já é ciúme,

O preto é a cor do luto

Cinza é a tristeza,

E o vermelho, a paixão.

O branco que é a cor mais pura,

É a paz no coração.

Mena Pinheiro (Jacareí, 1949)

24 Esperança devaneio semeado,

Nalgum tempo que nunca vai chegar,

Pois o bem que foi imaginado, 
Já se desfez, esgarçado no ar.

Rafael Lofrano (Taquaritinga, 1950)

Saudade

25

I Saudade estrada comprida

Comprida e sem contramão,

De um lado a alegria perdida,

E do outro a solidão!

II Amarga fundo no peito

Estraçalha o coração,

Não mata, não tem jeito,

E não existe solução!

III Lembranças de entes queridos,

Presença de velhos amores,

Impressão dos tempos perdidos,

Doce mistura de prazer e dores.

IV É deixar que ela venha,

Silenciosa, mansa, devagar,

Sorrir quando assim convenha

E quando for o caso, chorar!

Zizica Nunes (Mogi das Cruzes, 1956)

26 Responda doutor Salomão,

Ao que eu lhe pergunto,

É melhor ser um doidão,

Que um calmo defunto?

Edgar (Hospital Espírita de Marília, 1995)

\section{Sabidas}

27 Deus não traça a sina de ninguém

Cada um vai fazendo o seu destino

Sabendo o que é mal, o que é bem

O que é verdade, o que é desatino!

Pedro Jalageas (Uraraí, 1932)

Se não chove até São José 
Arrume a trouxa e sua famiage, Pegue logo a estrada, dê no pé, Pra se livrar da triste estiage!

Seo Pedro (Crato, 1969)

29 Cuidado com muita gente

Que a gente vê que não presta!

Se atira uma pedra pra frente

A pedra lhe volta pra testa!

Sr. Fernandes, delegado e farmacêutico (Uraraí, 1932)

30 Sou tribufú - isso não me amola,

Só lhe peço perdoar a impertinença,

Sou eu hoje quem pede esmola,

Amanhã não será vossa incelença?

Um bêbado (Salvador, Engenho Velho de Brotas, 1969)

31 Pra quem diz que Deus não existe:

Ele sabe disso, fica brabo?

Você faz figura triste,

Perseguin seu próprio rabo!

Dadico (Jacareí, 1949)

32 Juntou tanta coisa, tanto dinheiro,

Tanto roubou, tanto mentiu, tanta loucura

Hoje o que ele tem de seu inteiro

São sete palmos de fundura.

Seo Selma (Poá, 1950)

33 "Corpo-Seco", duro, arreganhado,

De quem em vida só praticou maldade,

Hoje grama maldito o seu pecado,

Morto-vivo por toda eternidade!

Daniel (Suzano, 1958)

34 Mulher dos outros pra ele era uma festa

Mas um dia, olhando-se no espelho,

Descobriu que bem no meio da testa

Tinha um monumental chavelho.

Num bar (Mogi das Cruzes, 1960)

35 Meu amigo tenha medo,

De gentes de ambição, 
Se você lhes dá um dedo, Elas lhe tomam a mão!

(Poá, 1962)

Cada panela tem seu cabo

Cada qual o seu caminho

Zé Prequeté olhe o seu rabo

Deixe em paz o rabo do vizinho!

(Poá, 1962)

37 Mulher veia é jabiraca

Home veio é defunto

Solteirona é jararaca,

Nego bebo é fedunto!

(Natal, 1969)

38 Vamos acabar co'a lambança

Basta de tanta embrulhação

Que vá pros quintos a poupança

E vá pro inferno a eleição.

Guarda Elpídio (Marília, 1989)

39 De grão em grão, diz o velho ditado,

A galinha vai enchendo o próprio papo.

Mas digo eu que sou juramentado:

De papo em papo os chatos enchem o saco!

Tita (João Pessoa, 1969)

40

Cada um tem sua sina

Cada qual o seu caminho

Mulher olhe o seu rabo,

Deixe o rabo do vizinho!

(Poá, 1962)

41 No final das andanças desta vida,

Entre doenças, dores e outros castigos,

Aguardando a hora por todos devida,

Você possa dizer eu tive amigos!

Reinaldo Pisseta ( Taquaritinga, 1965)

42 Muitos lutam por fortuna e sorte,

Infinito poder, máxima riqueza,

Mas no pico dessa árdua empresa, 
O quinhão de todos é a certeira morte!

Rafael Lofrano (Taquatitinga, 1968)

43 Meu amor se assegure,

Crea no que ocê não sabe:

Não há bem que sempre dure

Nem mal que nunca acabe!

(Poá, 1968)

44 A Leira é fềmea que vai gerar Tombe a terra, separe a sementeira, Não are fundo pra não machucar, Deite a semente, chame a chuva criadeira!

(Marília, 1969)

45 Esta vida é interminável escola.

Quanta gente de meu conhecimento,

Que parece por fora bela viola

Mas por dentro só é pão bolorento!

(Suzano, 1970)

\section{Safadas}

46 Em mulherão de bigode, E homem de fala fina, Dê paulada se você pode, Ou atire de carabina!

47 Cada terra tem seu uso, Cada canto uma etiqueta, Em Itapetininga, um abuso Só se come de gaveta!

Chico Laranjal (Pilar, 1937)

48 Em Taubaté tenha cuidado, Se quiser ficar inteiro.

Saia de lá bem ligeiro, Se já não estiver berganhado!

Chico Laranjal (Pilar, 1937)

49 De cavalo pangaré, De muié que mija em pé, 
De home de Taubaté,

Libera nobis, dominé!

Chico Laranjal (Pilar, 1937)

50 A mulher do delegado,

Pra poder se distrair,

Mata pulga co'o machado,

Se o delegado vai dormir!

Didi Castilho, sobre antigos acontecimentos em Santa Adélia (1942)

51 Comadre, essa sua amiguinha,

De narizinho inxerido,

Co esse ar de minininha,

Vai ingrupir seu marido!

Didi Castilho (Taquaritinga, 1941)

52 A mulher do "Seo" Josias,

Tem mania de grandeza,

Toma banho de bacia,

Diz que nadou na represa!

Didi Castilho (Taquaritinga, 1942)

53 Prefeito de olho gordo e mão comprida,

Inveja os outros, rouba tudo que pode

Quem sabe da sua vida,

Quando nem puxava rabo de bode.

Didi Castilho (Taquaritinga, 1942)

54 O povo olha pra todos os lados

E só vê politicalha indecente

Que já vem de plano jurado

De roubar e encher o saco da gente!

(Jaboticabal, 1946)

55 Quem por acaso já foi sentenciado,

E não tem nenhuma profissão,

Candidate-se a senador ou deputado,

Pra esses tipos ideiaram a eleição!

(Jaboticabal, 1946)

56 Burro que faz atchim,

Mulher que sabe latim, 
Home que é ri-ririm,

Fiquem longe de mim!

Cabeção (Suzano, 1959)

57 Namorei uma menina

Que não tinha quinze ano,

A pobre não tinha peito,

Ponharo peito de pano.

Um menino (Poá, 1960)

58 Ai! Tanto preconceito existe,

Nesta querida terra nossa:

Moças de Curralinho refugam

Os moços de Ponta Grossa.

Um chofer de táxi (São Paulo, 1973)

59 Caborge de arrenegado,

Se tira com pau de fumo.

Da pimenta, tire o sumo,

E lhe dê cristel demorado!

Totonho Mineiro (Marília, 1974)

60 Foi na cidade de Geremoabo,

Terra de gente brava e decente,

Que o diabo deu uma de valente

E lá perdeu chifres e rabo!

O pedreiro Gerolino (São Paulo, 1974)

61 Por favor, senhor presidente

Jure pra mim, fique frio:

Você não vai sair de baiana

$\mathrm{Na}$ festa do ronquinrio!

Elpidio (Marília, 1991)

62 Te dou um conselho compadre,

Que me parece bem justo:

Não ergas saia de padre,

Que tu vais levar um susto!

(Marília, 1990)

63 Cai tanto raio em peroba,

Em bicharada e na gente,

Por mais que o povo roga, 
Só não cai nesse presidente!

Elpídio (Marília, 1991)

64 São Gonçalo do Amarante,

Meu santo casamenteiro,

Me arrume mulher bonita,

Que tenha muito dinheiro!

(Marília, 1991)

65 Inventor de tanto plano,

De caretas e berros mil,

Porque ainda neste ano,

Não desencarna do Brasil!

Elpídio (Marília, 1991)

66 Podes fazer o maior alarde

Sei que tua língua não se agüenta:

Colírio caprichado de pimenta

Nos olhos dos outros não arde!

Zé Inácio (Marília, 1991)

Do fundo da memória

67 Até outro dia sinhô.

Até outro dia sinhá.

Que o cativeiro acabou.

Agora vamos dançar,

Agora vamos cantar,

Que o sol da liberdade

Da Princesa já raiou!

Mãe Domingas (Pilar, 1922).

Teve filhos: Iria, Silvéria,

Paulino. Morren em 1936.

Conta que havia poucos

escravos em Pilar. A

familia Almeida Leite

alforriou os seus escra-

vos e doou-lhes terras,

antes de 13 de maio de 1888 .

A terra doada, ela chamava

de terra dos pretos, e fica-

va nas bandas de Sarapui. 
Uma louvação a São Benedito

68

I Que santo é aquele

Que vem no andor?

È São Benedito

Com Nosso Senhor

II Oh! São Benedito

Da manga cheirosa

Cheirando a jasmim

Cheirando a rosa!

III Oh! São Benedito

De muita graça

Que ronca no peito

E bebe cachaça!

IV Oh! São Benedito

No meio de espinhos

Meu Santo bendito

Me abre os caminhos!

V Meu São Benedito,

Olho de vidraça,

Descobre mentira

Desmancha trapaça.

VI Oh! São Benedito

De muita valia

Me abre os caminhos

De noite e de dia!

VII Que seja louvado

Este Santo bendito

Em nome de Deus

Do Senhor Jesus Cristo !

Iracema Nunes coletou.

Caputera, Reza para São

Benedito, (1939).

Capelão João Cruz (Ilha dos Búzios, 1952) 


\section{Roda infantil}

De uma ronda infantil em Poá, quase defronte à rua do Campo, junto à Capela de Santo Antonio (1942).

69 As crianças cantam:

Menina da perna torta,

Da saia espandongada,

Boca de jacaré,

Faz favor de entrar na roda,

Diga um verso bem bonito

E vá s' mbora.

Uma por uma das meninas declamou:

70

I Sete e sete são catorze

Com mais sete, vinte e um

Tenho sete namorados

Mas não gosto de nenhum

II Eu fui indo prum caminho

Capim cortou meu pé

Amarrei com fita verde

Cabelinho de José

III Sou pequenininha

De perna grossa

Vestido curto

Mamãe não gosta!

IV Batatinha quando nasce

Se esparrama pelo chão

Criancinha quando dorme

Põe a mão no coração !

V Atirei um cravo n' água,

De pesado foi ao fundo.

Os peixinhos responderam

Viva Dom Pedro II

VI Da laranja quero um gomo

Do limão quero um pedaço

Da mamãezinha querida

Eu quero um grande abraço 
VII Um passarinho me disse Enquanto fazia seu ninho Trate de mim com amor, Que eu the dou o meu carinho

VIII No fim desta rua Existe um casarão Lá estão papai, mamãe, Lá mora meu coração!

\section{Sujas}

71 Adeus fazenda da fome

Nunca mais me verás tu Criei ferrugem na boca

Teia de aranha no cu.

Galvão (Jaboticabal, 1943)

72 Quando o bumbum cresce,

Isso é sinal muito triste, É que o pipi então desce,

Nunca mais "esperto" em riste!

Querido (Jaboticabal, 1944)

73 Estou ficando velho

Estou ficando feio

Estou com o pinto mole

Estou com o saco cheio.

Celino Pimentel (Jaboticabal, 1944)

74 O amor é uma cobiça,

Que entra pr'os olhos,

Coça virilha

E sai pela pica!

Benedito Castilho (Taquaritinga, 1945)

75 Por favor senhor presidente,

Dê um trato na cachola,

Você tem cabeça de gente,

Ou é só cabeça da pistola?!

Elpídio (Marília, 1991) 
Você tem o saco roxo, De beringela e urucum? Antes que fique chocho, Enfie o tal no bumbum! Elpidio (Marília, 1991)

Duas coisas neste mundo, São de chamar a atenção; A bunda do Sigismundo, E do Padre Inácio o culhão!

Edgar (Hospital Espírita de Marília, abril, 1995)

Notas

1 ANDRADE, Carlos Drummond de. O compositor e seu Festival. In: $\mathrm{Ca}-$ deira de balanço. Rio de Janeiro, José Olympio Editora, 1966.

2 CALVINO, Ítalo. Ovídio e a contiguidade universal. In: Trad. de N. Moulin. São Paulo, Cia. das Letras, 1993, p. 31.

3 BLOCH, Raymond \& COUSIN, Jean. Roma e seu destino. Trad. de M. A. M. Godinho. Lisboa/Rio de Janeiro, Cosmos, 1964, p. 406-411.

4 BENJAMIN, Walter. Teses sobre filsofia da história. In: KOTHE, Flávio. (org.) Walter Benjamin. Trad. de F. Kothe. São Paulo, Ática, 1985, p. 155, tese 3.

Oswaldo Elias Xidieh é professor aposentado da Unesp-Marília e autor de inúmeros estudos sobre cultura popular. Publicou Narrativas populares (São Paulo, Belo Horizonte, Edusp/Itatiaia, 1993) e Semana Santa Cabocla (São Paulo, Instituto de Estudos Brasileiros, 1972). 